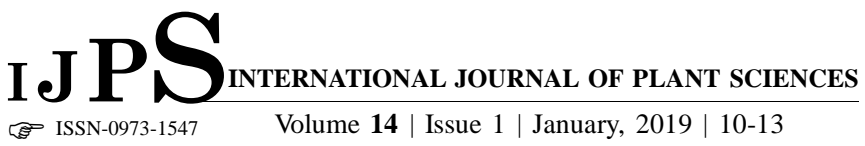

\title{
ResearchArticle
}

\section{Yield maximization in okra through nutrient interventions in typic ustipsamments of Kerala, India}

\author{
V. Mini and Usha Mathew
}

\section{SUMMARY}

A study was conducted in the typic ustipsamments of Kerala in India to assess the available micronutrient status of the region to develop a multi micronutrient mixture for balanced crop nutrition and to evaluate the effect of multi micronutrient mixture on growth and yield of okra. Chemical analysis of 200 georeferenced soil samples from the region revealed deficiencies of boron (77\%), zinc (66\%) and copper (53\%). A customized micronutrient mixture with a composition of Zn $(9.5 \%)+\mathrm{B}(2.6 \%)+\mathrm{Cu}(1.2 \%)+\mathrm{Mg}(2.4 \%)+\mathrm{N}(0.46 \%) @ 20 \mathrm{~kg} \mathrm{ha}^{-1}$ was developed based on the available micronutrient status of the region and crop requirement. Effect of micronutrient mixture was assessed in field experiments using okra variety Varsha Uphar as the test crop with nine treatments in three replications. Growth, yield and quality of okra increased significantly due to multi micronutrient mixture. Application of soil test based NPK and secondary nutrients + foliar application of 0.5 per cent solution of computed dose of micronutrient mixture @ $5 \mathrm{~kg} \mathrm{ha}^{-1}$ in two splits at 15 DAS and 30DAS $\left(\mathrm{T}_{7}\right)$ yielded significantly higher $\left(11.3 \mathrm{t} \mathrm{ha}^{-1}\right)$ with a $\mathrm{B}$ : $\mathrm{C}$ ratio of 3.02. Application of micronutrient mixtures customized for soil and crop ensures increased yield and sustain soil health.

Key Words : Typic ustipsamments, Micronutrients, Customized mixture, Okra

How to cite this article : Mini, V. and Mathew, Usha (2019). Yield maximization in okra through nutrient interventions in typic ustipsamments of Kerala, India. Internat. J. Plant Sci., 14 (1): 10-13, DOI: 10.15740/HAS/IJPS/14.1/10-13, Copyright@ 2019: Hind Agri-Horticultural Society.

Article chronicle : Received : 03.09.2018; Revised : 03.12.2018; Accepted : 11.12.2018

MEMBERS OF THE RESEARCH FORUM

Author to be contacted :

V. Mini, Onattukara Regional Agricultural Research Station (K.A.U.),

Kayamkulam (Kerala) India

Email : minisvilas@gmail.com

Address of the Co-authors:

Usha Mathew, College of Agriculture, Vellayani, Trivandrum, (Kerala) India 